\title{
Problematization, Method of Achieving Technology Transfer in Pomiculture at the University of Agricultural Sciences and Veterinary Medicine of Cluj-Napoca
}

\author{
Liana Maria VAC ${ }^{1}$, Sebastian-Călin VAC ${ }^{1 *}$, Viorel MITRE ${ }^{1}$, Andreea Flavia TRIPON ${ }^{1}$, Ionel PAPUC ${ }^{2}$ \\ ${ }^{1}$ Faculty of Horticulture, University of Agricultural Sciences and Veterinary Medicine of Cluj Napoca, \\ 3-5, Mănăștur Street, Cluj Napoca, Romania; \\ ${ }^{2}$ Faculty of Veterinary Medicine, University of Agricultural Sciences and Veterinary Medicine of Cluj \\ Napoca, 3-5, Mănăștur Street, Cluj Napoca, Romania \\ *Corresponding author: calin.vac@usamvcluj.ro
}

Bulletin USAMV series Agriculture 72(2)/2015

Print ISSN 1843-5246; Electronic ISSN 1843-5386

DOI 10.15835/buasvmcn-agr: 11741

\begin{abstract}
Based on the problems facing our contemporary society, it is necessary to identify modern methods and techniques of teaching and learning, adapted to economic and social environment. This will facilitate both assimilation by students more easily of information, practical skills required to integrate more easily into the labor market, but will bring significant benefits to economic and social environment, providing graduates able to respond to actual challenges, which will lead to shorter periods of adjustment and integration in the workplace. Also, in this way will be facilitated technology transfer between academia and the social and economic environment, one of the basic approaches of contemporary society. This research aims to highlight the role of problematization in achieving technology transfer between academia and economic environment, taking as concrete example the establishment of the new Didactic and Experimental orchard from the University of Agricultural Sciences and Veterinary Medicine of Cluj Napoca. Materials used in the analysis consisted of human resources (students of Faculty of Horticulture, teachers, PhD students, engineers, experts), material base (the orchard, farm machines and equipment) and problem situations they faced. The methods used were the methods of analysis and solving the problem, and theoretical generalization method. The conclusion is that relying on concrete problem situations, problematization is one of the most important methods of identifying and achieving technology transfer in pomiculture and not only.
\end{abstract}

Keywords: problematization, technology transfer, pomiculture, education methods, Romania.

\section{INTRODUCTION}

Problematization is the way to create in the mind of the student a state (situation) of conflict (critical or anxiety) intellectual positive, driven by the necessity of knowing an object, phenomenon, process or solving a theoretical or practical problem in a logical-mathematical and (or) experimental way (Pater, 2010). Problematization is a new method, modern, active-participatory nature, formative and heuristic able to determine independent work, to train and to develop intellectual abilities, imagination and logical thinking, of investigation and exploration, productive and creative, by formulating hypotheses, varied solutions to solve (application). It helps to transform the student in the subject of education, in participant acquiring new knowledge, making it possible to mobilize the personality resources and to bring satisfactions on all its plans: cognitive, affective, aesthetic, actional. A problematization-based teaching activity increases learning efficiency (Pater, 2010). 
Considering the changes in teaching and the demand for new ways of dealing with knowledge in higher learning, some brazilian experts discuss about problematization as an innovative methodological approache (Cyrino and TorallesPereira, 2004). In their opinion, problematization, focused on knowledge construction in the context of the formation of a critical awareness, contributes to a review of the teaching and learning process. Other colleagues countrymen with them take into account the need for an educational reform that should include in the pedagogical process a grasp of integrality, articulation, dialogue and problematization, so as to prepare the future professionals for instrumentalizing with responsibility and commitment (Correa et all, 2005).

Other authors identified three key dimensions of dialogic schooling, all of which are grounded in a fourth: the form of dialogical group discourse called community of philosophical inquiry, which is based on the problematization and reconstruction of concepts through critical argumentation (Kennedy, 2014).

There are also studies that examine the way educational technology researchers identify their research problems (problem situations), so they can find and follow a solution (Bahcekapili et all, 2013). Scope of the problem was identified as influential in terms of limiting the problem and identifying the problem. The results of the study are expected to be beneficial for educational technology researchers.

Technical universities in Romania in recent years promotes a problematization oriented formative teaching and based on systematic scientific knowledge. It is the case of Technical University "Gheorghe Asachi" of Iasi, which, for example, in 2014 Operational Plan (http:// www.cm.tuiasi.ro/docs/Plan_operational_2014. pdf) of the Faculty of Construction Machines and Industrial Management considers that this approach is essential in achieving its mission. The pedagogical quality of didactic method assumes its transformation from a knowledge way proposed by teacher in a learning way actually made by student within the formal and non-formal, with openings to education (Cristea, 2009).

On the other hand, the term "technology transfer" is used to describe the process by which ideas and concepts are moved from the laboratory to marketplace (Phillips, 2002; Williams \& Gibson, 1990). Another authors have attempted a broader definition where they apreciate that technology transfer is the movement of knowledge, skill, organisation, values and capital from the point of generation to the site of adaptation and application (Mittleman and Pasha, 1997).

Based on the problems facing our contemporary society, it is necessary to identify methods and modern techniques of teaching and learning, adapted to economic and social environment. This will facilitate both assimilation by students more easily of information, practical skills required to integrate more easily into the labor market, but will bring significant benefits to economic and social environment, providing graduates able to respond to actual challenges, which will lead to shorter periods of adjustment and integration in the workplace (Vac, 2015). Also, in this way will be facilitated technology transfer between academia and the social and economic environment, one of the basic approaches of contemporary society (Manolea, 2012).

Analysing the two concepts, respectivelly "problematization" and "technology transfer", it can be easily observe that the first is could have an important role in achieving the second one. Unfortunatelly, there are no studies to analyse the relation between this two concepts, respectivelly "problematization" and "technology transfer". So, this research aims to highlight the role of problematization in achieving technology transfer between academia and economic environment, taking a concrete example in the field of pomiculture.

\section{MATERIALS AND METHODS}

This study proposed to create a problem situation for students, taking as concrete example the establishment of the new Didactic and Experimental orchard from the University of Agricultural Sciences and Veterinary Medicine of Cluj Napoca (UASVM): 2.4 ha of land, located close to the building of the Faculty of Horticulture.

The materials used in the article consisted of three categories:

1. The human resources:

a) first, the students of Faculty of Horticulture, who need to learn a practical lesson. This experiment involved 383 students from the following disciplines: 
- Horticulture: 64 stud. (2 ${ }^{\text {nd }}$ year), 53 stud. (3 ${ }^{\text {nd }}$ year), 42 stud. ( $4^{\text {nd }}$ year);

- Landscape: 44 stud. ( $2^{\text {nd }}$ year $), 64$ stud. $\left(3^{\text {nd }}\right.$ year), 62 stud. ( $4^{\text {nd }}$ year);

- Land measuremeants: 54 stud. ( $4^{\text {nd }}$ year).

b) second, a team of UASVM researchers, who have proposed to teach their students a practical lesson: 2 PhD professors, $3 \mathrm{PhD}$ students, 4 agronom engineers;

c) an external experts team of anti-hail installations, contracted by the university to implement such an installation: 2 experts.

2. The material base:

- 2.4 ha of land (the old Didactic and Experimental UASVM Orchard), located in Cluj-Napoca, 3-5 Manastur Street, Romania, in the UASVM campus, close to the building of the Faculty of Horticulture;

- 2 chainsaws, 4 tractors, 1 excavator, 2 trailers, other necessary devices;

- 3.000 fruit trees of 180 varieties.

3 . The concrete problem situation they faced: old orchard was old and unproductive. They should replace this old orchard with a new one, using new and productive species, but also a modern planting system and crop protection (an antihail installation - 1.9 ha of anti-hail mesh).

The most important method that has been used in the study was problematization: creating as many as possible problem situations for analyse by the students. During the teaching periods of students, it have been used methods of analysis, synthesis (exemplification) and theoretical generalization method - which means that the same way to operate in the field of pomiculture could be used in any other horticulture area.

\section{RESULTS AND DISCUSSION}

Starting from the technology transfer mechanisms detailed in specialized works (Barton, 2007), the authors consider that, generally speaking, related to the realities of Romania, the most important mechanisms applied in Romania are:

- contract research (academia <--> economics): contracts (usually research consortia) between academia entities (universities, research/ innovation centers/institutes) and economic entities to develop research activities in partnership, or technological developments;
- consultations (academia $<==>$ economics): mechanism of "service", depending on the situation, both can be suppliers or customers;

- licensing (academia, economics ==> economics): arrangements whereby academic research results, patents, or resulting from the technological development of a company are transferred to another entity for operation;

- funding projects (academia, economics): financing projects for infrastructure, equipments research, production/technological lines;

- research projects (academia): financing projects for research activities, conducted by national or international funding bodies;

- company interships (economics): transfer of skills and competencies between participants to the transfer (from trainer to the trained staff);

- spin-offs (academia + economics =-= economics): new entities (usually companies) founded by a research group from academia, to implement technical activities as a consequence of research and innovation.

In this study, it has been used the following categories of technology transfer mechanisms, as in Fig. 1:

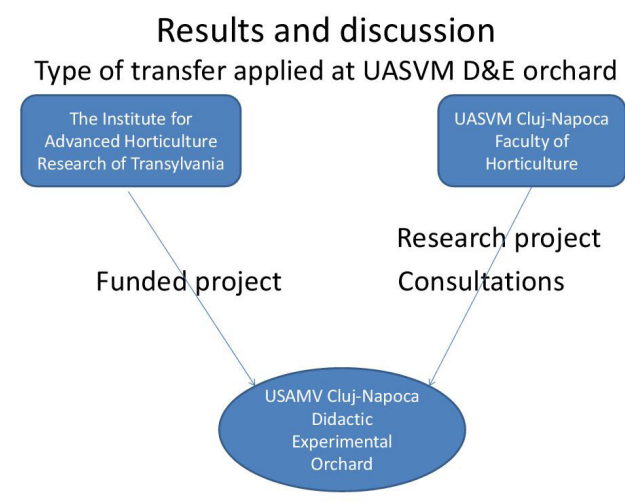

Fig. 1. Types of technology transfer applied at UASVM Didactic and Experimental Orchard

These technology transfer mechanisms are detailed bellow:

- funding projects: the anti-hail installation have been procured within the UASVM grant financed project "The Institute for Advanced Horticulture Research of Transylvania", SMIS 946/14064, ctr. no. 248/28.09.2010 with National Authority for Scientific Research and Innovation, as In- 
termediate Body, in the name and for the Ministry of Economy, Commerce and Business Environment as Management Authority for the Operational Programme "Increase of Economic Competitiveness";

- research project: in 2012, the management board of the Faculty of Horticulture of UASVM launched a challenge for the Department of Pomiculture, to develop a research project consisting of establishment of a new experimental orchards, replacing the old didactic and experimental orchard. During the 2012-2013 period, the teachers and the students from the Department of Pomiculture developed a research project to implement in 2014, for this purpose;

- consultations: to install the anti-hail installation in the new orchard, at the beginning of 2014 the management board of the Faculty of Horticulture of UASVM contracted a specialized company in anti-hail installations.

The challenges for this study was to identify and apply the most related modern methods and techniques for teaching and learning to the economic and social environment, to get directly benefits both to academia and socio-economics (Fig. 2).

UASVM Cluj-Napoca, being an applied university, owning and working its own didactic experimental orchard, where problem situations could be easily identified and were within a natural environment, they could be addressed and solved practical rather more easily, while developing students' practical skills for solving that will be useful in their future work. In this regard, the need to install the anti-hail installation represented the most actual and complex problem situation that the students have faced, being constantly guided by the experts in the field of anti-hail.

In order to solve this problem situations, the teachers team detalied and followed 4 steps plan (Fig. 3):

Step 1. Disband the old orchard, which requires: - cut the old trees, using the 2 chainsaws;

- take out the roots, using the excavator;

- transport and valorisation, using the 4 tractors and the 2 trailers;

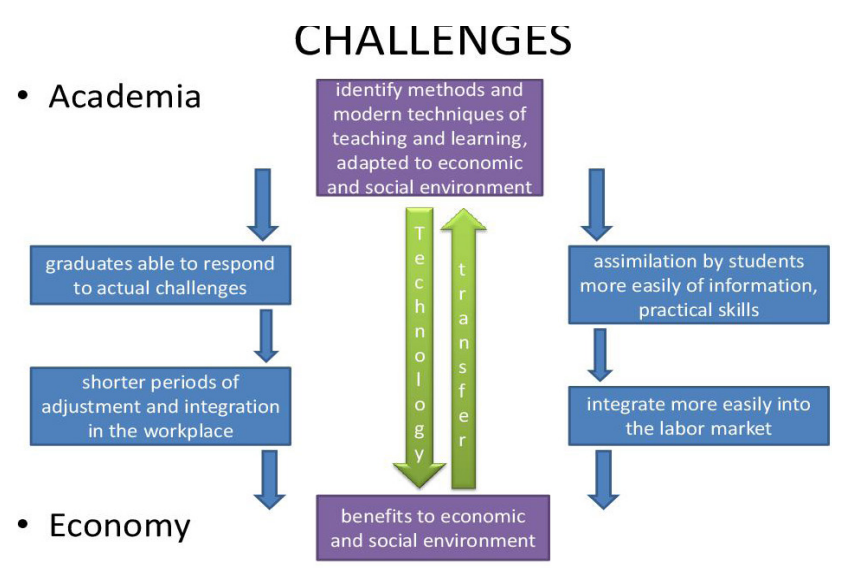

Fig. 2. Challenges for UASVM students

\section{Results and discussion Problematization applied to UASVM D\&E Orchard}
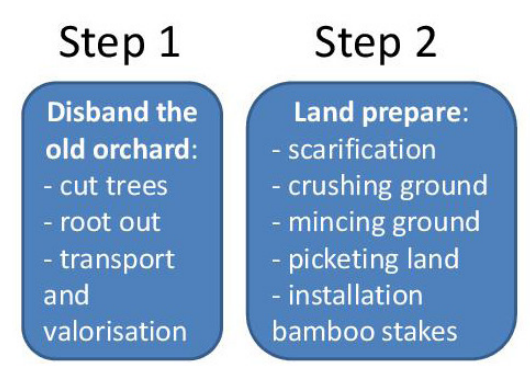

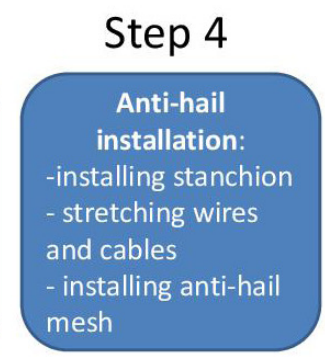

Stage 1: analysing the concrete situation problems

Fig. 3. Steps to solve problem situations at UASVM Didactic and Experimental Orchard 
Human resources involved: the 4 engineers, the students. Time need: 4 weeks. All wood material have been used at the Didactic and Experimental Farm of Cojocna, which belong to UASVM Cluj-Napoca: wood mass was crumbled, then chopped and used in thermal power plants that provide heating in livestock farms.

Step 2. Land prepare, which requires:

- scarification the land, using 1 powerful tractor and a scarification device;

- crushing ground, using 1 tractor and a crushing device;

- mincing ground, using 1 tractor and a mincing device;

- picketing land, by the Land measuremeants students;

- installation bamboo stakes, by the students and engineers, using the excavator;

Human resources involved: the 4 engineers, the students. Time need: 2 weeks.

Step 3. Establish the new orchard, which requires:

- making holes;

- miring and molding roots;

- planting trees;

- watering trees;

Human resources involved: the 4 engineers, the students. Time need: 3 weeks.

Step 4. Install the anti-hail installation, which requires:

- installing stanchion;

- stretching wires and cables;

- installing anti-hail mesh.

Human resources involved: the 4 engineers, the students, the 2 experts. Time need: 3 weeks.

Total elapsed time: 12 weeks.

All the activities were coordinated by the two $\mathrm{PhD}$ professors (the first one for technical and managerial issues, technical skills, and the second one for problematization - situation problems defined, data collecting) and the $3 \mathrm{PhD}$ students, who provided full support research and knowledge transfer along entire period.

On the other hand, the schedule was followed very closed during its implementation and it managed to arouse the interest of the entire team (especially teachers and students). Direct benefits both recorded during the experiment, and in future periods were as follows:
- gaining students' experience in the fruit growing (planting, cutting, fertilizing, irrigation, harvesting fruit) and anti-hail installations;

- students education factor: making performance;

- proving UASVM Cluj-Napoca as an applied university;

- low costs for establishing the new didacticexperimental orchard;

- over half of students of IV Horticulture focused their undergraduate study on a practice direction and planed to follow an applied master in Horticulture domain. More than that, some of them expressed their interest to pursue a Ph.D. at UASVM Cluj-Napoca!

\section{CONCLUSION}

The problem situation descripted above, respectivelly establishment of the new Didactic and Experimental orchard from the University of Agricultural Sciences and Veterinary Medicine of Cluj Napoca, brought a number of benefits for the actors involved:

- assimilation by students more easily of information and get practical skills;

- help the students to integrate more easily into the labor market and to need shorter periods of adjustment and integration in the workplace;

- the university formed graduates able to respond to actual challenges;

- teachers had the opportunity to illustrate in practice the theoretical knowledge through practical appropriate activities. At the same time, they gave a positive example to the other departments of the Faculty of Horticulture, which will have to find similar problem situations, to prepare their own students at least at the same level;

- following a teaching and research experiment, the external experts benefited from a contract that has brought benefits to their own companies;

- the university had to gain from this experiment, because otherwise it would have been forced to resort only to external experts, whose costs would be much higher. On the other hand, the university has achieved an important objective, assumed by its Charter: to form students with strong practical skills, ready to integrate more quickly in economic and social environment.

Relying on concrete problem situations, problematization is one of the most important methods of identifying and achieving technology 
transfer in pomiculture and in any other applied didactic or research area.

\section{REFERENCES}

1. Bahcekapili E, Bahcekapili T, Erumit SF, Goktas Y, Sozbilir M (2013). The Factors Affecting Definition of Research Problems in Educational Technology Researches. Kuram ve Uygulamada Egitim Bilimleri. 13(4):2330-2335

2. Barton JH (2007). New Trends in Technology Transfer. Implications for National and International Policy". ICTSD, Geneva

3. Corrêa LB, Lunard, VL, De Conto SM, Galiazzi M (2005) The understanding of solid waste from healthcare services in academic education: a contribution to environmental education. Interface - Comunicação, Saúde, Educação, Botucatu. 9(18):571-584

4. Cristea S (2009). Studies of general pedagogy. Didactic and Pedagogical Bucharest

5. Cyrino EG, Toralles-Pereira ML, (2004). Discoverybased teaching and learning strategies in health: problematization and problem-based learning. Cadernos de Saúde Pública. 20(3):780-788
6. Kennedy D (2014). Neoteny, Dialogic Education and an Emergent Psychoculture: Notes on Theory and Practice. Journal of Philosophy of Education. 48 (1): 100-117

7. Manolea G (2012). Valorisation the creative potential of universities by innovation and technology transfer. AGIR Bulletin, University of Craiova

8. Mittleman JH, Pasha MK (1997). Out from Underdevelopment Revisited: Changing Global Structures and the Remarking of the Third World. St. Martin's Press, New York

9. Pater S (2010). Specialty's didactics - Course for students of Engineering, http://imt.uoradea.ro/mecatronica/ curslab.html

10. Phillips R (2002). Technology Business Incubators: How Effective Is Technology Transfer Mechanisms?. Technology in Society. 24 (3): 299-316

11. Vac LM (2015). Problematization, modern teaching method applied in pomiculture. PhD thesis in developing

12. William F, Gibson DV (1990). Technology Transfer: A Communication Perspective. Sage: Beverly Hills, CA

13. *** Technical University "Gheorghe Asachi" Iasi (UT Iasi), Faculty of Construction Machines and Industrial Management, Operational Plan 2014, http://www. cm.tuiasi.ro/docs/Plan_operational_2014.pdf 